\title{
Differential Regulation of a7 Nicotinic Receptor Gene (CHRNA7) Expression in Schizophrenic Smokers
}

\author{
Sharon Mexal ${ }^{3}$, Ralph Berger ${ }^{1}$, Judy Logel ${ }^{1}$, Randal G. Ross ${ }^{1}$, Robert Freedman ${ }^{1,2}$, and \\ Sherry Leonard 1,2 \\ Sharon Mexal: ; Ralph Berger: ; Judy Logel: ; Randal G. Ross: ; Robert Freedman: ; Sherry Leonard: \\ Sherry.Leonard@ucdenver.edu \\ ${ }^{1}$ Department of Psychiatry, University of Colorado Denver, Mail Stop 8344, P.O. Box 6511, Aurora, \\ CO 80045, USA \\ 2 The Veterans Affairs Medical Research Service, Denver, CO, USA \\ ${ }^{3}$ Cenomed BioSciences, Irvine, CA, USA
}

\begin{abstract}
The $\alpha 7$ neuronal nicotinic receptor gene (CHRNA7) has been implicated in the pathophysiology of schizophrenia by genetic and pharmacological studies. Expression of the $\alpha 7^{*}$ receptor, as measured by $\left[{ }^{125} \mathrm{I}\right] \alpha$-bungarotoxin autoradiography, is decreased in postmortem brain of schizophrenic subjects compared to non-mentally ill controls. Most schizophrenic patients are heavy smokers, with high levels of serum cotinine. Smoking changes the expression of multiple genes and differentially regulates gene expression in schizophrenic hippocampus. We examined the effects of smoking on CHRNA7 expression in the same tissue and find that smoking differentially regulates expression of both mRNA and protein for this gene. CHRNA7 mRNA and protein levels are significantly lower in schizophrenic nonsmokers compared to control nonsmokers and are brought to control levels in schizophrenic smokers. Sufficient protein but low surface expression of the $\alpha 7^{*}$ receptor, seen in the autoradiographic studies, suggests aberrant assembly or trafficking of the receptor.
\end{abstract}

\section{Keywords}

Nicotinic receptor; Schizophrenia; Smoking; Gene expression; $\alpha$ 7; CHRNA7

\section{Introduction}

The development of schizophrenia is thought to involve the interaction of multiple genetic, epigenetic, and environmental factors (Harrison and Weinberger 2005). One of the candidate genes for schizophrenia, the $\alpha 7$ neuronal nicotinic acetylcholine receptor gene, CHRNA7, and its holoreceptor, $\alpha 7^{*}$, may also contribute to the high incidence of smoking in this population. The $\alpha 7^{*}$ receptor is a member of a large gene family that includes 14 known genes expressed in the central nervous system and in the periphery (Leonard and Bertrand 2001; Lindstrom 1997). Receptor subunits assemble as pentamers (Cooper et al. 1991) in the endoplasmic reticulum and migrate through the golgi to the cell surface (Cooper and Millar 1997; Green and Millar 1995; Wanamaker et al. 2003). The $\alpha 7^{*}$ receptor is thought to be a homopentamer that binds nicotine with low affinity and binds the snake toxin, $\alpha$-bungarotoxin, with high

Correspondence to: Sherry Leonard, Sherry . Leonard@ucdenver. edu. 
affinity (Wonnacott 1986; Wonnacott et al. 2005). Activation by the endogenous ligand, acetylcholine, or nicotine in tobacco products results in channel opening and increased intracellular $\mathrm{Ca}^{++}$(Vijayaraghavan et al. 1992). Presynaptically, $\mathrm{Ca}^{++}$influx leads to neurotransmitter release (Grady et al. 1992; Guo et al. 1998; Jones and Wonnacott 2004; Kaiser and Wonnacott 2000; MacDermott et al. 1999; Rousseau et al. 2005; Wonnacott 1997). Localization and $\mathrm{Ca}^{++}$influx at postsynaptic sites, likely in or near postsynaptic densities, can lead to changes in gene expression (Albuquerque et al. 1998; Levy and Aoki 2002; Maggi et al. 2003; Mexal et al. 2005; Shoop et al. 1999).

The CHRNA7 gene has been implicated in cognitive and sensory deficits in schizophrenia by both genetic and pharmacological studies. Schizophrenics have several types of sensory processing deficits, including auditory sensory processing (Adler et al. 1991; Freedman et al. 1999) and eye-tracking abnormalities (Holzman et al. 1973; Levy et al. 1993; Ross et al. 1998). Both of these deficits are normalized by nicotine, delivered as gum, or by smoking (Adler et al. 1993; Olincy et al. 1998; Olincy et al. 2003). In animal models of the P50 auditory sensory processing deficit, nicotine and specific agonists of the $\alpha 7^{*}$ receptor normalize the deficit (Simosky et al. 2001; Stevens et al. 1998). Nicotine also improves cognitive deficits in schizophrenia (George et al. 2002; Levin et al. 1999, 2006; Weiser et al. 2004), and the $\alpha 7^{*}$ receptor has been identified as an important target for the development of drugs for cognitive deficits in the disorder (Kuehn 2006). Indeed, Phase I and II trials of the CHRNA7 partial agonist, DMXB-A, found significant improvement in attention in nonsmoking schizophrenics (Freedman et al. 2008; Olincy et al. 2006). The locus of the CHRNA7 gene has been genetically linked to the sensory processing deficit in schizophrenia (Freedman et al. 1997) and to the disease in multiple studies (Abecasis and Cookson 2000; Freedman et al. 2001; Kaufmann et al. 1998; Leonard et al. 1998; Liu et al. 2001; Riley et al. 2000; Stöber et al. 2000; Tsuang et al. 2001; Xu et al. 2001). It is also linked to smoking in the disorder (De Luca et al. 2004).

We have previously screened the coding region and proximal promoter of the CHRNA7 gene in control and schizophrenic subjects. We did not find mutations in the coding region that were associated with schizophrenia (Gault et al. 2003). However, we did isolate mutations in the proximal promoter region that were associated with both schizophrenia and the P50 sensory processing deficit (Leonard et al. 2002). Many of these mutations functionally decrease transcription in a reporter gene assay.

The prevalence of smoking in schizophrenia is inordinately high. More than $80 \%$ of schizophrenics smoke compared to 25\% of the general population (Dalack et al. 1998; de Leon and Diaz 2005; George and Krystal 2000; Kumari and Postma 2005). Schizophrenics smoke high-tar cigarettes and extract more nicotine per cigarette than do normal smokers (Olincy et al. 1997).

The expression of the $\alpha 7^{*}$ receptor, as measured by $\left[{ }^{125} \mathrm{I}\right]-\alpha$-bungarotoxin binding, is decreased by approximately $50 \%$ in postmortem hippocampus of schizophrenic subjects (Freedman et al. 1995). Receptor expression is also reduced in cortex (Guan et al. 1999; Marutle et al. 2001) and in the reticular nucleus of the thalamus (Court et al. 1999). These data suggest that schizophrenics may be smoking to self-medicate some of the underlying pathology in the disorder (Adler et al. 1998; Leonard 2003; Leonard et al. 2007).

We have recently found that smoking changes gene expression for more than 250 genes in postmortem hippocampus (Mexal et al. 2005). Some of the expression changes may be long lasting (Hope et al. 2007). In the same microarray study, we found that many genes were differentially regulated by smoking in schizophrenic subjects. The pattern was generally the same. Expression was either increased or decreased in schizophrenic nonsmokers compared to control nonsmokers and at control levels in schizophrenic smokers. One of these genes, 
differentially regulated by smoking in schizophrenia, was the CHRNA7 gene. We have examined the relationship between mRNA and protein expression for the CHRNA7 gene in postmortem hippocampus of schizophrenic and control smokers and nonsmokers, finding that expression is differentially regulated in schizophrenic subjects. Both mRNA and protein are increased in schizophrenic smokers compared to controls. CHRNA7 promoter polymorphisms that decrease transcription in an in vitro reporter gene assay were found more frequently in schizophrenic nonsmokers with low levels of mRNA in hippocampus.

\section{Materials and Methods}

\section{Human Postmortem Brain Collection}

The Schizophrenia Research Center Brain Bank at the VA Medical Center in Denver, CO, provided postmortem brain tissue. Human brain was collected at autopsy from local services following family consent. At autopsy, the brain was weighed and examined for gross pathology. It was then divided sagittally, and one hemisphere, selected randomly, was preserved in formalin for neuropathological analysis at macroscopic and microscopic levels. Microscopic evaluations included standard Bielchowsky silver stain on multiple cerebral areas to rule out abnormal neuropathology, such as plaques and tangles, associated with Alzheimer's and other conditions. Patients with positive neuritic findings or ambiguous neuropathology reports were excluded from the current study. The hemisphere that was not subjected to neuropathological analysis was sliced coronally into $1-\mathrm{cm}$ slices. Multiple regions were dissected in 1-g blocks, frozen in dry ice snow, and packaged for storage at $-80^{\circ} \mathrm{C}$.

Hippocampal tissue for the microarray study was derived from coronal Section 5. Each sample included CA4, CA3, CA2, CA1, and subiculum. Brain hemisphere, left or right, was randomly collected. Freeze delay, the time from brain removal to storage of the dissected tissue at $-80^{\circ}$ $\mathrm{C}$, was always less than $2.5 \mathrm{~h}$ (Leonard et al. 1993). Brain pH measurement and RNA and protein isolation were carried out as previously described (Mexal et al. 2005, 2006).

\section{Subjects}

Subjects included in the mutation screening study were ascertained in the Denver Schizophrenia Center. DNA samples were isolated by standard methods from lymphoblasts or postmortem brain (Sambrook and Russell 2001).

Subjects included in the postmortem brain studies were selected after a review of records detailing pre- and postmortem parameters. This information was collected from an extensive review of hospital, autopsy, and neuropathology reports, as well as structured interviews with physicians and family, as previously described (Mexal et al. 2005). Briefly, subjects with neuropathological abnormalities, heavy alcohol use (>10 drinks per week), or illicit drug use were excluded from the study. Schizophrenics were selected using the narrow diagnostic criteria defined by the DSM-IV. Based on the records described above, two psychiatrists (RGR and RF) independently confirmed each patient's schizophrenia diagnosis and verified that controls had no history of mental illness. Patient records were also used to identify smokers and nonsmokers for this study. These records indicated packs of cigarettes smoked per day and pack years. A subject was included as a smoker in this study if that individual had been smoking any amount of cigarettes at the time of death. Nonsmokers included in the postmortem expression studies were selected if records indicated no history of smoking in the past 10 years. Several former smokers met this criterion and were, therefore, classified as nonsmokers in this study. Only never smokers were included in the mutation screening study.

Among the living subjects, controls were interviewed and found to have no evidence for current or past psychosis, using a Structured Clinical Interview for DSM-IV Axis I Disorders-Non- 
Patient Edition (First et al. 1996). They also received a Family History-Research Diagnostic Criteria interview (Endicott J. et al. 1978). Living schizophrenics were interviewed and diagnosis confirmed using the narrow diagnostic criteria defined by the DSM-IV (American Psychiatric Association 1994).

Ethnicities of all subjects were recorded from self-report or family interview. The majority of the postmortem brain subjects included in the array analysis were Caucasian (91.2\%). In order to match our expanded dataset utilized in our genotyping study to the postmortem brain samples, the majority of subjects included in this analysis were also Caucasian (approximately 99\%). Three types of analysis were done in the current study: Microarray, real-time quantitative PCR (QRT-PCR), and western blot. A summary of the demographics on samples included in each analysis are shown in Table 1.

\section{QRT-PCR}

Total RNA was isolated and integrity verified as described (Leonard et al. 2005; Mexal et al. $2005,2006,2007)$. Single-strand cDNA was synthesized from total RNA ( $2 \mu \mathrm{g})$ using random hexamer primers and the Superscript First-Strand Synthesis System for RT-PCR (Invitrogen, Carlsbad, CA). To limit amplification from genomic DNA, primer sets for each gene were designed to cross intron/exon boundaries (OligoToolkit, http://oligos.qiagen.com/oligos/toolkit.php). BLAST searches were performed to confirm primer specificity. Primer sequences are listed in Table 2.

PCR amplification of cDNA was performed using $500 \mathrm{nM}$ of primers and the Quantitect SYBR Green PCR Kit (Qiagen, Valencia, CA). PCR cycling conditions were $50^{\circ} \mathrm{C}$ for $2 \mathrm{~min}, 95^{\circ} \mathrm{C}$ for $15 \mathrm{~min}$, then 40 cycles of $94^{\circ} \mathrm{C}$ for $15 \mathrm{~s}, 58^{\circ} \mathrm{C}$ for $30 \mathrm{~s}$, and $72^{\circ} \mathrm{C}$ for $30 \mathrm{~s}$. Formation of PCR products was monitored using an iCycler detection system (BioRad, Hercules, CA). Linear regression was performed by the iCycler software (BioRad) to extrapolate mRNA amounts in nanograms from a standard curve. Values were normalized to the GAPDH mRNA levels. For each experiment, a tube without the addition of reverse transcriptase enzyme or without the addition of cDNA was included to assess amplification from genomic DNA and nonspecific product formation, respectively. A melt curve analysis was also conducted to examine the uniformity of product formation, primer-dimer formation, and amplification of nonspecific products.

\section{CHRNA7 Promoter Polymorphism Screening}

CHRNA7 promoter polymorphisms were screened, utilizing DFPLC technology (WAVE ${ }^{\mathrm{TM}}$, Transgenomic, Inc., San Jose, CA). For the proximal promoter polymorphism screening, a 271-base pair PCR product was amplified using a primer set spanning -269 to +2 of the gene (Table 2). Primers (600 nM) and DNA (500 ng) were combined with the GC-RICH PCR System (Roche Diagnostics, Indian-apolis, Ind). PCR amplification was performed in a GeneAmp PCR System 9600 (Perkin-Elmer) with the following conditions: $95^{\circ} \mathrm{C}, 3 \mathrm{~min} ; 95^{\circ} \mathrm{C}, 30$ $\mathrm{s} ; 60^{\circ} \mathrm{C}, 30 \mathrm{~s} ; 72^{\circ} \mathrm{C}, 30 \mathrm{~s}, 38$ cycles; $4^{\circ} \mathrm{C}$ hold. An aliquot of the PCR fragment was used for heteroduplex formation in the thermal cycler as follows: $95^{\circ} \mathrm{C}$ for $5 \mathrm{~min}$, ramp from $95^{\circ} \mathrm{C}$ to $25^{\circ} \mathrm{C}$ over $45 \mathrm{~min}$, hold at $4^{\circ} \mathrm{C}$. A melting profile for the fragment was determined with the Wavemaker program (Transgenomic, Inc). The resulting chromatograms showed the presence of heteroduplex peaks that were resolved optimally at $70.2^{\circ} \mathrm{C}$. A triethylammonium acetate and acetonitrile gradient specified by the manufacturer was used for elution.

\section{Western Blotting}

Western blotting was performed and analyzed as previously described (Mexal et al. 2005). The blotted membranes were blocked for $1 \mathrm{~h}$ in 5\% powdered milk diluted with Tris-buffered saline with $0.5 \%$ Tween- 20 at room temperature and overnight at $4{ }^{\circ} \mathrm{C}$ with the appropriate primary 
antibody: goat anti-GAPDH (SC-20357; Santa Cruz Biotechnology), 1:1,000 dilution and goat anti- $\alpha 7 *$ (SC-1447, Santa Cruz Biotechnology), 1:1,000 dilution. The specificity of this antibody was first assessed using human skin fibroblasts, which do not express detectable levels of $\alpha 7^{*}$ receptors. Consistent with previous findings, we did not detect any antibody reactivity in lanes loaded with fibroblast protein homogenate (data not shown). Expression levels for $\alpha 7^{*}$ were normalized to GAPDH levels.

\section{Statistical Analysis}

All statistical analyses were performed using SPSS (two-way ANOVA; SPSS version 9, SPSS, Chicago, IL). QRT-PCR and western blot data were imported into Excel. Relative expression values were $\log _{10}$ transformed and a two-way analysis of variance was utilized as the primary statistical tool to detect significant changes in gene expression due to the main effect of schizophrenia or to the interaction of schizophrenia and smoking. Post hoc comparisons were conducted using Tukey's statistical analysis. Differences in mean gene expression were determined using a two-tailed Student's $t$ test ( $p<0.05$, Excel). Mean relative expression levels $( \pm$ SEM) for each experimental group were graphed in Sigma Plot 2000 (SPSS). The distribution of CHRNA7 genotypes across smoking and diagnostic groups was evaluated by a Fisher's exact test.

Continuous variables, including age, brain $\mathrm{pH}$, freezer storage time, and postmortem interval (PMI), were evaluated by two-way ANOVA to determine if there were any significant differences across the four subject groups for our expression studies. These variables were also correlated with gene expression.

To determine whether gender or agonal state was significantly different across the mental illness and control groups, a Fisher's exact test was performed. The effect of gender, a categorical variable, was also evaluated by two-way ANOVA, smoking $\times$ gender effects, or three-way ANOVA, for smoking $\times$ schizophrenia $\times$ gender. To assess whether agonal state (Li et al. 2004; Mexal et al. 2006) affected mRNA or protein levels of the CHRNA7 gene, the expression for subjects who suffered fast deaths (agonal scores of 1 or 2) was compared to those who experienced intermediate to slow deaths (agonal scores of 3 or 4 ) by a Student's $t$ test (Excel).

Other potential confounds, including alcohol use and antipsychotic drug use, were investigated. The effects of alcohol on gene expression were assessed by reanalyzing the data using a Student's $t$ test (Excel) after excluding subjects who had used alcohol at the time of death. Antipsychotic drug use was investigated in the QRT-PCR analysis of the interactive effects of smoking and schizophrenia, which included three drug-naïve patients. Gene expression was compared by ANOVA between these unmedicated subjects and patients treated with either typical neuroleptics $(n=11)$ or those who were on atypicals $(n=4)$.

\section{Results \\ Demographics}

This study characterized the hippocampal gene expression profile for the $\alpha 7$ nicotinic receptor gene, CHRNA7, in control nonsmokers, control smokers, schizophrenic non-smokers, and schizophrenic smokers. Hippocampus from a total of 17 schizophrenics and 17 controls was analyzed by QRT-PCR (Table 1). In the western blot studies, 35 subjects were studied, 15 of which were included in the QRT-PCR experiments. 


\section{Gene Expression Analysis of the Interactive Effects of Schizophrenia $\times$ Smoking on CHRNA7 mRNA Expression}

Several candidate genes displayed reduced expression in schizophrenic nonsmokers compared to all controls and schizophrenic smokers in our earlier microarray study (Mexal et al. 2005). These genes included the $\alpha 7$ nicotinic acetylcholine receptor subunit (CHRNA7). The CHRNA7 gene is partially duplicated on the same chromosome (15q14) (Gault et al. 1998; Riley et al. 2002). Exons 5-10 of the full-length gene were duplicated in a large duplicon, which interrupted a partial duplication of a second gene. The chimeric gene, CHRFAM7A, is expressed as mRNA, and the $\alpha 7$ containing sequences are $99.9 \%$ homologous to the full-length CHRNA7 gene (Gault et al. 1998; Riley et al. 2002). The function of the duplicated gene is not known. QRT-PCR was performed to differentiate the expression of the two highly homologous transcripts, CHRNA7 and CHRFAM7A. Schizophrenic nonsmokers displayed reduced expression levels of the full-length CHRNA7 gene relative to control nonsmokers and schizophrenic smokers in the microarray analysis (Fig. 1). The probes on the Applied Biosystem's gene chip were localized in the $3^{\prime}$ untranslated region of the gene. This region is duplicated in CHRFAM7A; the probes, thus, detect both the full-length CHRNA7 gene and CHRFAM7A. Primer sets were designed to specifically amplify either CHRNA7 or CHRFAM7A (Fig. 2a). Exponential amplification of CHRNA7 was detected 10 cycles prior to the amplification of CHRFAM7A (data not shown), suggesting that the latter transcript is expressed at much lower levels than the full-length transcript in the human hippocampus. CHRFAM7A expression was not evaluated across groups; QRT-PCR conditions could not be optimized due to the limited detection of this transcript in postmortem human brain. However, consistent with the microarray findings, QRT-PCR with the specific primer sets detected significantly lower CHRNA7 levels in schizophrenic nonsmokers compared to control nonsmokers and schizophrenic smokers (Fig. 2).

A similar gene expression pattern was also observed at the protein level (Fig. 2b). The reported CHRNA7 expression by QRT-PCR and western blot analyses was not correlated with continuous variables such as age, $\mathrm{pH}, \mathrm{PMI}$, and storage time ( $p>0.05)$, and categorical parameters such as gender, agonal state, and alcohol use did not contribute to the expression changes (three-way ANOVA, $p>0.05$ ). Moreover, similar CHRNA7 mRNA expression levels $(p>0.05)$ were detected by QRT-PCR between the three drug-naïve patients, nine patients on typical antipsychotics, and four on atypicals, suggesting that this transcript was not altered by medication history $(p>0.05)$.

\section{Genetic Variation at CHRNA7 and mRNA Expression}

Single nucleotide polymorphisms within the 231-base pair core promoter of the CHRNA7 gene have previously been shown by a luciferase reporter gene assay to significantly alter promoter activity in vitro, suggesting that transcription may be altered in individuals with these mutations (Leonard et al. 2002). Subjects evaluated in the current expression analysis were, therefore, screened for these polymorphisms, and possible correlations between genotype and CHRNA7 mRNA expression were investigated. Overall, three proximal promoter polymorphisms were identified in our sample set, including $-86 \mathrm{C} / \mathrm{T},-194 \mathrm{G} / \mathrm{C}$, and $-46 \mathrm{G} /$ $\mathrm{T}$ (numbering with respect to exon 1), all of which have been associated with significantly reduced luciferase expression in a reporter gene assay (Leonard et al. 2002). Schizophrenic nonsmokers had a greater proportion of promoter polymorphisms than control nonsmokers and schizophrenic smokers (Table 3), the two cohorts which displayed significantly greater mRNA expression than the schizophrenic nonsmoker group (Fig. 2b). However, the difference did not reach statistical significance. To investigate a possible association of promoter mutations with schizophrenic nonsmokers, we utilized an expanded DNA dataset from the laboratory that included Caucasian subjects collected locally in the Schizophrenia Center. This sample included a total of 48 control nonsmokers, 18 control smokers, 44 schizophrenic nonsmokers, 
and 146 schizophrenic smokers. The increased sample revealed a statistically significant difference in the genotypic distributions between these groups with schizophrenic nonsmokers having a greater number of promoter variants (Table 3; schizophrenic nonsmokers versus control nonsmokers, $p=0.0276$; schizophrenic nonsmoker versus schizophrenic smoker, $p=0.0174$, Fisher's exact test, one-tailed).

\section{Discussion}

The $\alpha 7$ nicotinic receptor gene, CHRNA7, has been associated with schizophrenia, the P50 deficit and smoking in schizophrenia (Leonard et al. 2001, 2007). Surface expression of the assembled, functional pentamer is decreased in multiple postmortem brain regions of schizophrenic subjects (Court et al. 1999; Freedman et al. 1995; Guan et al. 1999; Marutle et al. 2001). Surface expression of low affinity $\alpha 7^{*}$ receptors, as measured by $\left[{ }^{125} \mathrm{I}\right]-\alpha-$ bungarotoxin in rodents, is only upregulated at high levels of nicotine (Marks et al. 1986). In humans, we found that $\left[{ }^{125} \mathrm{I}\right]-\alpha$-bungarotoxin binding was increased in postmortem hippocampus of smokers but the increase was not significant (Breese et al. 2000). Other investigators do not find a difference (Court et al. 1999). Thus, binding may only increase in brain of very heavy smokers. De Luca et al. (2004) recently reported that there is no significant difference in CHRNA7 mRNA expression levels in dorsolateral prefrontal cortex between schizophrenics and controls. However, detailed smoking histories for subjects in this study were not available.

Our current data show that both CHRNA7 mRNA and protein expression were reduced in schizophrenic non-smokers relative to controls. In schizophrenic smokers, CHRNA7 mRNA and protein expression is normal. Promoter mutations in the CHRNA7 proximal promoter have been associated with decreased transcription and are found more frequently in schizophrenic subjects and controls with sensory-processing deficits (Leonard et al. 2002). Schizophrenic nonsmokers, in whom low levels of CHRNA7 mRNA were found, appear to have a significantly greater proportion of promoter polymorphism compared to the other groups evaluated in this study. Moreover, and consistent with our in vitro findings (Leonard et al. 2002), we observed reduced CHRNA7 mRNA expression in subjects carrying a promoter polymorphism, regardless of diagnosis and/or smoking status, although the difference was not significant. While a larger sample size is needed to accurately determine the significance of this association, reduced CHRNA7 mRNA expression in schizophrenic nonsmokers could be due to the greater proportion of subjects carrying a promoter polymorphism compared to control nonsmokers and schizophrenic smokers. We also examined the relationship of CHRNA7 promoter polymorphism to nonsmoking status in a larger, genotyped set (Table 3). With this increased number of subjects, we found significantly more promoter mutations in schizophrenic nonsmokers than in either control nonsmokers or schizophrenic smokers. This is consistent with our result in postmortem hippocampus and suggests that promoter polymorphism may account for low levels of CHRNA7 mRNA in schizophrenic nonsmokers.

Our results also indicate that adequate intracellular protein for $\alpha 7^{*}$ receptor expression is present in schizophrenic smokers. We conclude that proper assembly of the receptor in the endoplasmic reticulum or trafficking of the holoreceptor to the cell surface is aberrant in schizophrenic patients. Disruption of the normal endoplasmic reticulum (ER) assembly process and/or maturation into competent surface receptors may, thus, account for decreased $\alpha 7^{*}$ receptor surface expression. These processes are not independent; improper assembly of receptors results in ER retention, and hence, a failure to reach the cell surface as functional receptors (Nicke et al. 2004; Sallette et al. 2004). The $\alpha 7$ subunit peptide crosses the membrane four times and is assembled as a pentamer. The initial step of receptor assembly is complex and inefficient (Wanamaker et al. 2003), a process influenced by posttranslational modifications of nAChRs (Drisdel et al. 2004; Sallette et al. 2005; Wanamaker et al. 2003), as 
well as interactions with the ubiquitin-proteosome pathway (Christianson and Green 2004; Ficklin et al. 2005; Wanamaker et al. 2003) and non-receptor accessory/chaperone proteins (Blount and Merlie 1991; Chang et al. 1997; Jeanclos et al. 2001; Keller and Taylor 1999; Ren et al. 2005; Williams et al. 2005). Clearly, further investigation of the cascade of events leading to $\alpha 7^{*}$ nAChR cell surface expression in schizophrenics compared to non-mentally ill subjects is warranted. Efforts have already been made in characterizing the processes leading to the membrane expression of NMDA receptors, another neurotransmitter receptor system implicated in schizophrenia. A recent study suggested that alterations in the glutamatergic system in schizophrenia may not be due to receptor expression changes but to the abnormal expression of interacting proteins that are responsible for the trafficking of these receptors from the endoplasmic reticulum to the cell surface (Kristiansen and Meador-Woodruff 2005). It is, therefore, possible that many disease susceptibility genes, including the CHRNA7, may be affected at common levels of regulation that have yet to be identified.

\section{Acknowledgments}

This work was supported by the National Institute on Drug Abuse (NIDA) DA09457, the National Institute on Mental Health (NIMH) MH081177 and MH068582, and the Veterans Affairs Medical Research Service. We are grateful to Bernadette Sullivan and Katy Walton for technical assistance.

\section{References}

Abecasis GR, Cookson WOC. GOLD—Graphical Overview of Linkage Disequilibrium. Bioinformatics 2000;16:182-183. [PubMed: 10842743]

Adler LE, Waldo MC, Nagamoto HT, Baker N, Franks R, Bickford-Wimer PC, et al. 10 Years of studies on P50 sensory gating - A review and considerations for future studies. Schizophrenia Research 1991;4:329.

Adler LE, Hoffer LD, Wiser A, Freedman R. Normalization of auditory physiology by cigarette smoking in schizophrenic patients. American Journal of Psychiatry 1993;150:1856-1861. [PubMed: 8238642]

Adler LE, Olincy A, Waldo MC, Harris JG, Griffith J, Stevens K, et al. Schizophrenia, sensory gating, and nicotinic receptors. Schizophrenia Bulletin 1998;24:189-202. [PubMed: 9613620]

Albuquerque EX, Pereira EF, Braga MF, Matsubayashi H, Alkondon M. Neuronal nicotinic receptors modulate synaptic function in the hippocampus and are sensitive to blockade by the convulsant strychnine and by the anti-Parkinson drug amantadine. Toxicology Letters 1998;102-103:211-218.

American Psychiatric Association. Diagnostic and statistical manual of mental disorders. Vol. 4. Arlington: American Psychiatric Association; 1994.

Blount P, Merlie JP. BIP associates with newly synthesized subunits of the mouse muscle nicotinic receptor. Journal of Cell Biology 1991;113:1125-1132. [PubMed: 2040645]

Breese CR, Lee MJ, Adams CE, Sullivan B, Logel J, Gillen KM, et al. Abnormal regulation of high affinity nicotinic receptors in subjects with schizophrenia. Neuropsycho-pharmacology 2000;23:351364.

Chang W, Gelman MS, Prives JM. Calnexin-dependent enhancement of nicotinic acetylcholine receptor assembly and surface expression. Journal of Biological Chemistry 1997;272:28925-28932. [PubMed: 9360963]

Christianson JC, Green WN. Regulation of nicotinic receptor expression by the ubiquitin-proteasome system. EMBO Journal 2004;23:4156-4165. [PubMed: 15483627]

Cooper ST, Millar NS. Host cell-specific folding and assembly of the neuronal nicotinic acetylcholine receptor a7. Journal of Neurochemistry 1997;68:2140-2151. [PubMed: 9109542]

Cooper E, Couturier S, Ballivet M. Pentameric structure and subunit stoichiometry of a neuronal nicotinic acetylcholine receptor. Nature 1991;350:235-238. [PubMed: 2005979]

Court J, Spurden D, Lloyd S, McKeith I, Ballard C, Cairns N, et al. Neuronal nicotinic receptors in dementia with Lewy bodies and schizophrenia: Alpha-bungarotoxin and nicotine binding in the thalamus. Journal of Neurochemistry 1999;73:1590-1597. [PubMed: 10501205] 
Dalack GW, Healy DJ, Meador-Woodruff JH. Nicotine dependence in schizophrenia: Clinical phenomena and laboratory findings. American Journal of Psychiatry 1998;155:1490-1501. [PubMed: 9812108]

de Leon J, Diaz FJ. A meta-analysis of worldwide studies demonstrates an association between schizophrenia and tobacco smoking behaviors. Schizophrenia Research 2005;76:135-157. [PubMed: 15949648]

De Luca V, Wong AHC, Muller DJ, Wong GWH, Tyndale RF, Kennedy JL. Evidence of association between smoking and alpha 7 nicotinic receptor subunit gene in schizophrenia patients. Neuropsychopharmacology 2004;29:1522-1526. [PubMed: 15100704]

Drisdel RC, Manzana E, Green WN. The role of palmitoylation in functional expression of nicotinic alpha7 receptors. Journal of Neuroscience 2004;24:10502-10510. [PubMed: 15548665]

Endicott, J.; Andreasen, NC.; Spitzer, RL. Family History-Research Diagnostic Criteria. Research Assessment and Training Unit, New York State Psychiatric Institute; NY: 1978.

Ficklin MB, Zhao S, Feng G. Ubiquilin-1 regulates nicotine-induced up-regulation of neuronal nicotinic acetylcholine receptors. Journal of Biological Chemistry 2005;280:34088-34095. [PubMed: 16091357]

First, MB.; Gibbon, M.; Spitzer, RL.; Williams, JBW. Structured clinical interview for axis I DSM-IV disorders-non-patient edition (SCID-I/NP, Version 2.0). New York: Biometrics Research; 1996.

Freedman R, Hall M, Adler LE, Leonard S. Evidence in postmortem brain tissue for decreased numbers of hippocampal nicotinic receptors in schizophrenia. Biological Psychiatry 1995;38:22-33. [PubMed: 7548469]

Freedman R, Coon H, MylesWorsley M, OrrUrtreger A, Olincy A, Davis A, et al. Linkage of a neurophysiological deficit in schizophrenia to a chromosome 15 locus. Proceedings of the National Academy of Sciences of the United States of America 1997;94:587-592. [PubMed: 9012828]

Freedman R, Adler LE, Leonard S. Alternative phenotypes for the complex genetics of schizophrenia. Biological Psychiatry 1999;45:551-558. [PubMed: 10088045]

Freedman R, Leonard S, Olincy A, Kaufmann CA, Malaspina D, Cloninger CR, et al. Evidence for the multigenic inheritance of schizophrenia. American Journal of Medical Genetics 2001;105:794-800. [PubMed: 11803533]

Freedman R, Olincy A, Buchanan RW, Harris JG, Gold JM, Johnson L, et al. Initial phase 2 trial of a nicotinic agonist in schizophrenia. American Journal of Psychiatry 2008;165(8):1040-1047. [PubMed: 18381905]

Gault J, Robinson M, Berger R, Drebing C, Logel J, Hopkins J, et al. Genomic organization and partial duplication of the human a7 neuronal nicotinic acetylcholine receptor gene. Genomics 1998;52:173185. [PubMed: 9782083]

Gault J, Hopkins J, Berger R, Drebing C, Logel J, Walton K, et al. Comparison of polymorphisms in the a7 nicotinic receptor gene and its partial duplication in schizophrenic and control subjects. American Journal of Medical Genetics 2003;123B:39-49. [PubMed: 14582144]

George TP, Krystal JH. Comorbidity of psychiatric and substance abuse disorders. Current Opinion in Psychiatry 2000;13:327-331.

George TP, Vessicchio JC, Termine A, Sahady DM, Head CA, Pepper WT, et al. Effects of smoking abstinence on visuospatial working memory function in schizophrenia. Neuropsychopharmacology 2002;26:75-85. [PubMed: 11751034]

Grady S, Marks MJ, Wonnacott S, Collins AC. Characterization of nicotinic receptor-mediated [3H] dopamine release from synaptosomes prepared from mouse striatum. Journal of Neurochemistry 1992;59:848-856. [PubMed: 1494911]

Green WN, Millar NS. Ion-channel assembly. Trends in Neurosciences 1995;18:280-287. [PubMed: 7571003]

Guan ZZ, Zhang X, Blennow K, Nordberg A. Decreased protein level of nicotinic receptor alpha7 subunit in the frontal cortex from schizophrenic brain. NeuroReport 1999;10:1779-1782. [PubMed: 10501574]

Guo JZ, Tredway TL, Chiappinelli VA. Glutamate and GABA release are enhanced by different subtypes of presynaptic nicotinic receptors in the lateral geniculate nucleus. Journal of Neuroscience 1998;18:1963-1969. [PubMed: 9482782] 
Harrison PJ, Weinberger DR. Schizophrenia genes, gene expression, and neuropathology: on the matter of their convergence. Molecular Psychiatry 2005;10:40-68. [PubMed: 15263907]

Holzman PS, Proctor LR, Hughes DW. Eye-tracking patterns in schizophrenia. Science 1973;181:179_ 181. [PubMed: 4711736]

Hope BT, Nagarkar D, Leonard S, Wise RA. Long-term upregulation of protein kinase a and adenylate cyclase levels in human smokers. Journal of Neuroscience 2007;27:1964-1972. [PubMed: 17314292]

Jeanclos EM, Lin L, Treuil MW, Rao J, DeCoster MA, Anand R. The chaperone protein 14-3-3 eta interacts with the nicotinic acetylcholine receptor alpha 4 subunit -Evidence for a dynamic role in subunit stabilization. Journal of Biological Chemistry 2001;276:28281-28290. [PubMed: 11352901]

Jones IW, Wonnacott S. Precise localization of alpha 7 nicotinic acetylcholine receptors on glutamatergic axon terminals in the rat ventral tegmental area. Journal of Neuroscience 2004;24:11244-11252. [PubMed: 15601930]

Kaiser S, Wonnacott S. alpha-Bungarotoxin-sensitive nicotinic receptors indirectly modulate [H-3] dopamine release in rat striatal slices via glutamate release. Molecular Pharmacology 2000;58:312318. [PubMed: 10908298]

Kaufmann CA, Suarez B, Malaspina D, Pepple J, Svrakic D, Markel PD, et al. NIMH genetics initiative millenium schizophrenia consortium: linkage analysis of African-American pedigrees. American Journal of Medical Genetics 1998;81:282-289. [PubMed: 9674972]

Keller SH, Taylor P. Determinants responsible for assembly of the nicotinic acetylcholine receptor. Journal of General Physiology 1999;113:171-176. [PubMed: 9925816]

Kristiansen LV, Meador-Woodruff JH. Abnormal striatal expression of transcripts encoding NMDA interacting PSD proteins in schizophrenia, bipolar disorder and major depression. Schizophrenia Research 2005;78:87-93. [PubMed: 16023328]

Kuehn BM. Link between smoking and mental illness may lead to treatments. Jama-Journal of the American Medical Association 2006;295:483-484.

Kumari V, Postma P. Nicotine use in schizophrenia: The self medication hypotheses. Neuroscience and Biobehavioral Reviews 2005;29:1021. [PubMed: 15964073]

Leonard S. Consequences of low levels of nicotinic acetylcholine receptors in schizophrenia for drug development. Drug Development Research 2003;60:127-136.

Leonard S, Bertrand D. Neuronal nicotinic receptors: From structure to function. Nicotine \& Tobacco Research 2001;3:203-223. [PubMed: 11506765]

Leonard S, Logel J, Luthman D, Casanova M, Kirch D, Freedman R. Biological stability of mRNA isolated from human postmortem brain collections. Biological Psychiatry 1993;33:456-466. [PubMed: 8098224]

Leonard S, Gault J, Moore T, Hopkins J, Robinson M, Olincy A, et al. Further investigation of a chromosome 15 locus in schizophrenia: Analysis of affected sibpairs from the NIMH genetics initiative. American Journal of Medical Genetics 1998;81:308-312. [PubMed: 9674976]

Leonard S, Adler LE, Benhammou K, Berger R, Breese CR, Drebing C, et al. Smoking and mental illness. Pharmacology, Biochemistry and Behavior 2001;70:561-570.

Leonard S, Gault J, Hopkins J, Logel J, Vianzon R, Short M, et al. Association of promoter variants in the alpha 7 nicotinic acetylcholine receptor subunit gene with an inhibitory deficit found in schizophrenia. Archives of General Psychiatry 2002;59:1085-1096. [PubMed: 12470124]

Leonard S, Berger R, Mexal S, Walton K, Freedman R. Comparison of gene expression in human cultured skin fibroblasts and postmortem brain: Neuregulin-1 expression is decreased in primary skin fibroblasts of schizophrenic subjects. Online. 2005 Program No. 815.7 Abstract Viewer/Itinerary Planner Society for Neuroscience.

Leonard S, Mexal S, Berger R, Olincy A, Freedman R. Smoking and schizophrenia: Evidence for self medication. Schizophrenia Bulletin 2007;33:262-263.

Levin ED, Bettegowda C, Blosser J, Gordon J. AR-R17779, an alpha 7 nicotinic agonist, improves learning and memory in rats. Behavioural Pharmacology 1999;10:675-680. [PubMed: 10780509]

Levin ED, McClernon FJ, Rezvani AH. Nicotinic effects on cognitive function: Behavioral characterization, pharmacological specification, and anatomic localization. Psychopharmacology 2006;184:523-539. [PubMed: 16220335] 
Levy RB, Aoki C. alpha 7 nicotinic acetylcholine receptors occur at postsynaptic densities of AMPA receptor-positive and -negative excitatory synapses in rat sensory cortex. Journal of Neuroscience 2002;22:5001-5015. [PubMed: 12077196]

Levy DL, Holzman PS, Matthysse S, Mendell NR. Eye tracking dysfunction and schizophrenia - a critical perspective. Schizophrenia Bulletin 1993;19:461-536. [PubMed: 8235455]

Li JZ, Vawter MP, Walsh DM, Tomita H, Evans SJ, Choudary PV, et al. Systematic changes in gene expression in postmortem human brains associated with tissue $\mathrm{pH}$ and terminal medical conditions. Human Molecular Genetics 2004;13:609-616. [PubMed: 14734628]

Lindstrom J. Nicotinic acetylcholine receptors in health and disease. [Review] [135 refs]. Molecular Neurobiology 1997;15:193-222. [PubMed: 9396010]

Liu CM, Hwu HG, Lin MW, Ou-Yang WC, Lee SFC, Fann CSJ, et al. Suggestive evidence for linkage of schizophrenia to markers at chromosome 15q13-14 in Taiwanese families. American Journal of Medical Genetics 2001;105:658-661. [PubMed: 11803511]

MacDermott AB, Role LW, Siegelbaum SA. Presynaptic ionotropic receptors and the control of transmitter release [Review]. Annual Review of Neuroscience 1999;22:443-485.

Maggi L, Le Magueresse C, Changeux JP, Cherubini E. Nicotine activates immature "silent" connections in the developing hippocampus. Proceedings of the National Academy of Sciences of the United States of America 2003;100:2059-2064. [PubMed: 12582205]

Marks MJ, Stitzel JA, Collins AC. A dose-response analysis of nicotine tolerance and receptor changes in two inbred mouse strains. Journal of Pharmacology and Experimental Therapeutics 1986;239:358364. [PubMed: 3772799]

Marutle A, Zhang X, Court J, Piggott M, Johnson M, Perry R, et al. Laminar distribution of nicotinic receptor subtypes in cortical regions in schizophrenia. Journal of Chemical Neuroanatomy 2001;22:115-126. [PubMed: 11470559]

Mexal S, Frank M, Berger R, Adams CE, Ross RG, Freedman R, et al. Differential modulation of gene expression in the NMDA postsynaptic density of schizophrenic and control smokers. Molecular Brain Research 2005;139:317-332. [PubMed: 16122832]

Mexal S, Berger R, Adams CE, Ross RG, Freedman R, Leonard S. Brain pH has a significant impact on human postmortem hippocampal gene expression profiles. Brain Research 2006;1106:1-11. [PubMed: 16843448]

Mexal S, Berger R, Pearce L, Barton A, Logel J, Adams CE, et al. Regulation of a novel aN-catenin splice variant in schizophrenic smokers. American Journal of Medical Genetics. Part B, Neuropsychiatric Genetics 2007;147B(6):759-768.

Nicke A, Thurau H, Sadtler S, Rettinger J, Schmalzing G. Assembly of nicotinic alpha7 subunits in Xenopus oocytes is partially blocked at the tetramer level. FEBS Letters 2004;575:52-58. [PubMed: 15388332]

Olincy A, Young DA, Freedman R. Increased levels of the nicotine metabolite cotinine in schizophrenic smokers compared to other smokers. Biological Psychiatry 1997;42:1-5. [PubMed: 9193735]

Olincy A, Ross RG, Young DA, Roath M, Freedman R. Improvement in smooth pursuit eye movements after cigarette smoking in schizophrenic patients. Neuropsychopharmacology 1998;18:175-185. [PubMed: 9471115]

Olincy A, Johnson LL, Ross RG. Differential effects of cigarette smoking on performance of a smooth pursuit and a saccadic eye movement task in schizophrenia. Psychiatry Research 2003;117:223-236. [PubMed: 12686365]

Olincy A, Harris JG, Johnson LL, Pender V, Kongs S, Allensworth D, et al. Proof-of-concept trial of an alpha 7 nicotinic agonist in schizophrenia. Archives of General Psychiatry 2006;63:630-638. [PubMed: 16754836]

Ren XQ, Cheng SB, Treuil MW, Mukherjee J, Rao J, Braunewell KH, et al. Structural determinants of alpha4beta2 nicotinic acetylcholine receptor trafficking. Journal of Neuroscience 2005;25:66766686. [PubMed: 16014729]

Riley BP, Makoff AM, Magudi-Carter M, Jenkins TJ, Williamson R, Collier DA, et al. Haplotype transmission disequilibrium and evidence for linkage of the CHRNA7 gene region to schizophrenia in Southern African Bantu families. American Journal of Medical Genetics 2000;96:196-201. [PubMed: 10893497] 
Riley B, Williamson M, Collier D, Wilkie H, Makoff A. A 3-Mb map of a large segmental duplication overlapping the alpha 7-nicotinic acetylcholine receptor gene (CHRNA7) at human 15q13-q14. Genomics 2002;79:197-209. [PubMed: 11829490]

Ross RG, Olincy A, Harris JG, Radant A, Adler LE, Freedman R. Anticipatory saccades during smooth pursuit eye movements and familial transmission of schizophrenia. Biological Psychiatry 1998;44:690-697. [PubMed: 9798072]

Rousseau SJ, Jones IW, Pullar IA, Wonnacott S. Presynaptic alpha 7 and non-alpha 7 nicotinic acetylcholine receptors modulate [H-3]D-aspartate release from rat frontal cortex in vitro. Neuropharmacology 2005;49:59-72. [PubMed: 15992581]

Sallette J, Bohler S, Benoit P, Soudant M, Pons S, Le Novere N, et al. An extracellular protein microdomain controls up-regulation of neuronal nicotinic acetylcholine receptors by nicotine. Journal of Biological Chemistry 2004;279:18767-18775. [PubMed: 14764595]

Sallette J, Pons S, Devillers-Thiery A, Soudant M, Prado de Carvalho L, Changeux JP, et al. Nicotine upregulates its own receptors through enhanced intracellular maturation. Neuron 2005;46:595-607. [PubMed: 15944128]

Sambrook, J.; Russell, DW. Molecular cloning: A laboratory manual. Vol. 3. Cold Spring Harbor: Cold Spring Harbor Laboratory Press; 2001.

Shoop RD, Martone ME, Yamada N, Ellisman MH, Berg DK. Neuronal acetylcholine receptors with alpha7 subunits are concentrated on somatic spines for synaptic signaling in embryonic chick ciliary ganglia. Journal of Neuroscience 1999;19:692-704. [PubMed: 9880590]

Simosky JK, Stevens KE, Kern WR, Freedman R. Intragastric DMXB-A, an alpha 7 nicotinic agonist, improves deficient sensory inhibition in DBA/2 mice. Biological Psychiatry 2001;50:493-500. [PubMed: 11600102]

Stevens KE, Kem WR, Mahnir VM, Freedman R. Selective alpha7-nicotinic agonists normalize inhibition of auditory response in DBA mice. Psychopharmacology 1998;136:320-327. [PubMed: 9600576]

Stöber G, Saar K, Rüschendorf F, Meyer J, Nürnberg G, Jatzke S, et al. Splitting schizophrenia: Periodic catatonia-susceptibility locus on chromosome 15q15. American Journal of Human Genetics 2000;67:1201-1207. [PubMed: 11001582]

Tsuang DW, Skol AD, Faraone SV, Bingham S, Young KA, Prabhudesai S, et al. Examination of genetic linkage of chromosome 15 to schizophrenia in a large veterans affairs cooperative study sample. American Journal of Medical Genetics 2001;105:662-668. [PubMed: 11803512]

Vijayaraghavan S, Pugh PC, Zhang ZW, Rathouz MM, Berg DK. Nicotinic receptors that bind abungarotoxin on neurons raise intracellular free Ca++ Neuron 1992;8:353-362. [PubMed: 1310863]

Wanamaker CP, Christianson JC, Green WN. Regulation of nicotinic acetylcholine receptor assembly. Annals of the New York Academy of Sciences 2003;998:66-80. [PubMed: 14592864]

Weiser M, Levin ED, George TP, Newhouse PA, Leonard S. Nicotinic receptor modulation of attention: An endophenotype for therapeutic drug development. Biological Psychiatry 2004;55:152S-152S.

Williams ME, Burton B, Urrutia A, Shcherbatko A, Chavez-Noriega LE, Cohen CJ, et al. Ric-3 promotes functional expression of the nicotinic acetylcholine receptor alpha7 subunit in mammalian cells. Journal of Biological Chemistry 2005;280:1257-1263. [PubMed: 15504725]

Wonnacott S. a-Bungarotoxin binds to low-affinity nicotine binding sites in rat brain. Journal of Neurochemistry 1986;47:1706-1712. [PubMed: 3772372]

Wonnacott S. Presynaptic nicotinic ACh receptors. [Review] [76 refs]. Trends in Neurosciences 1997;20:92-98. [PubMed: 9023878]

Wonnacott S, Sidhpura N, Balfour DJK. Nicotine: from molecular mechanisms to behaviour. Current Opinion in Pharmacology 2005;5:53-59. [PubMed: 15661626]

Xu JZ, Pato MT, Dalla Torre C, Medeiros H, Carvalho C, Basile VS, et al. Evidence for linkage disequilibrium between the alpha 7- nicotinic receptor gene (CHRNA7) locus and schizophrenia in Azorean families. American Journal of Medical Genetics 2001;105:669-674. [PubMed: 11803513] 


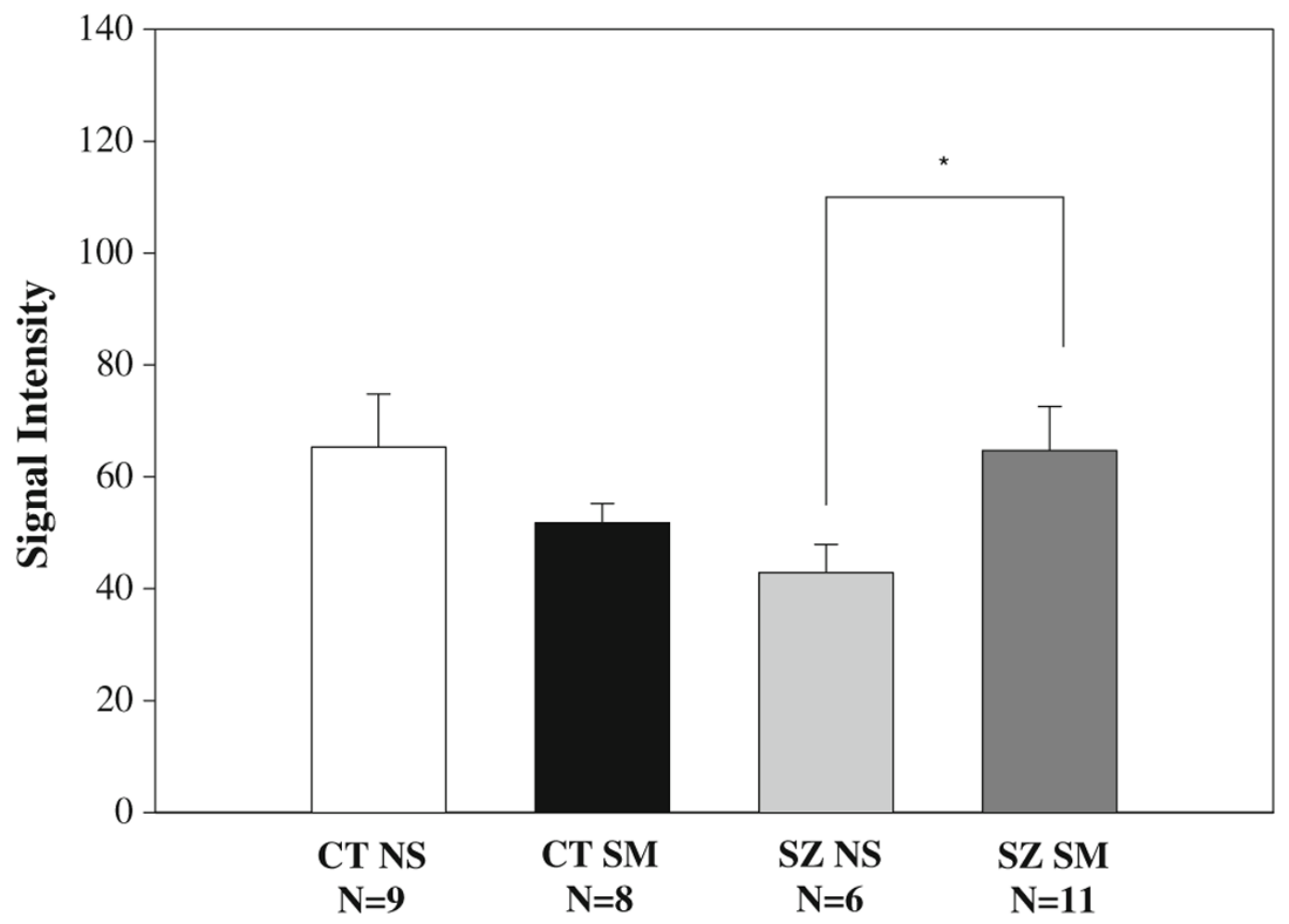

Figure 1.

CHRNA7 signal intensity is significantly reduced in schizophrenic nonsmokers compared to schizophrenic smokers. The probe set for CHRNA7 on the oligonucleotide array detected significantly reduced signal intensity in schizophrenic nonsmokers compared to patient smokers. ${ }^{*} p<0.05$ 
a

\section{dupCHRNA7

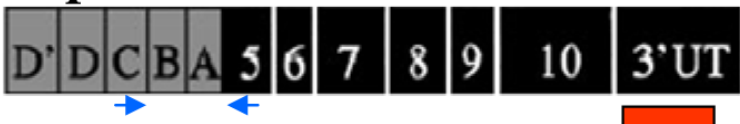

(1)(1) (3) (1) (3)

(6)
CHRNA7

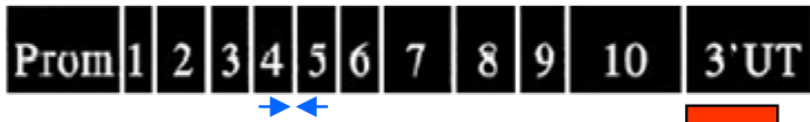

$(12) *(1)$

(1)

(1)

(4)

\section{Affymetrix probeset}

\section{$\rightarrow \leftarrow$ QRT-PCR primers}

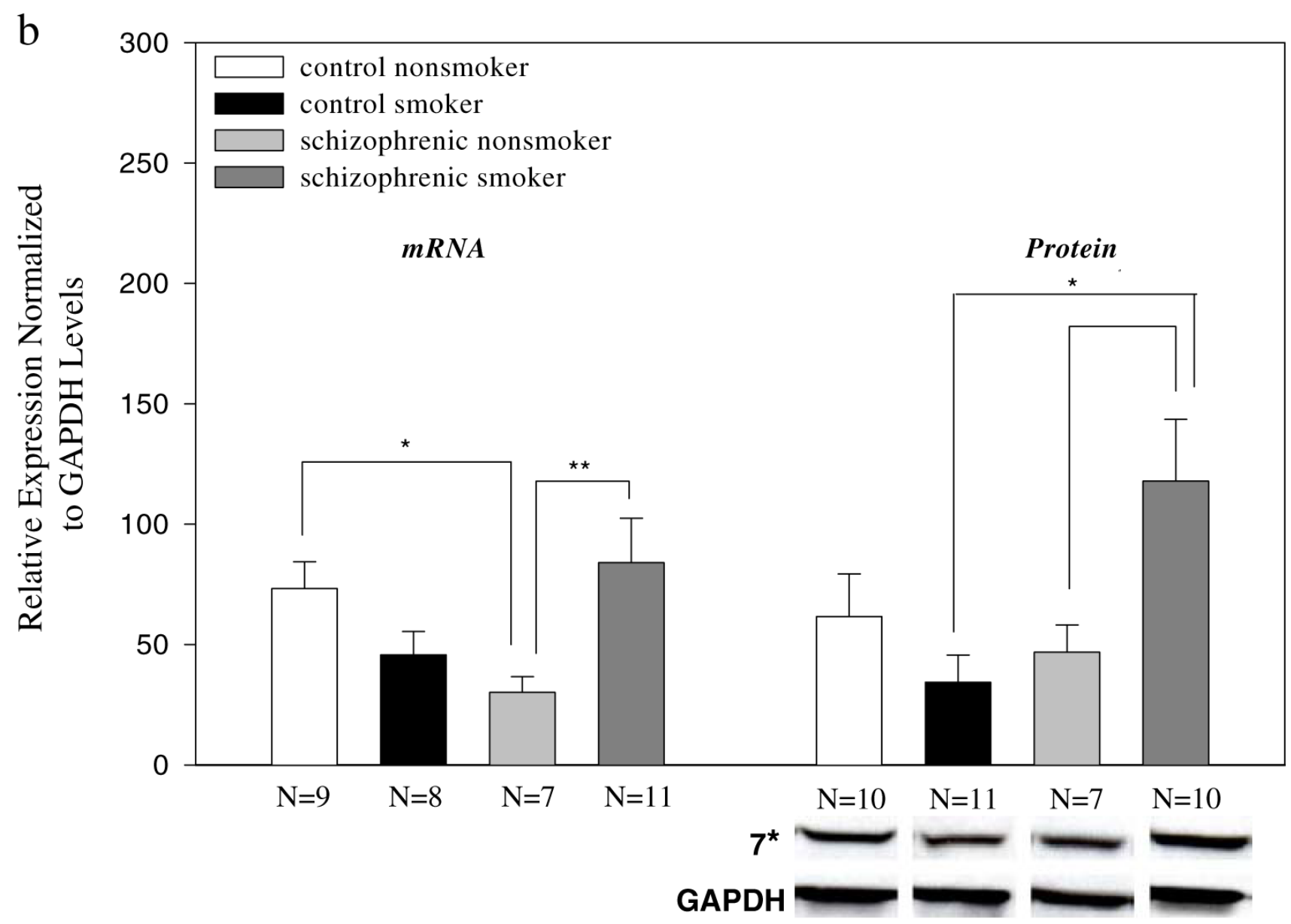

Figure 2.

CHRNA7 displays reduced mRNA and protein levels in schizophrenic nonsmokers. a The microarray probe set for $C H R N A 7$, shown in red, was designed to detect expression from both the full-length CHRNA7 and the duplicated fusion gene, CHRFAM7A. b Reduced $\alpha 7 \mathrm{nAChR}$ mRNA expression was observed in schizophrenic nonsmokers relative to smokers by RT-PCR and western blot analyses. QRT-PCR primers, shown in blue (a), were designed to specifically amplify either CHRFAM7A or CHRNA7. Schizophrenic nonsmokers displayed significantly reduced $\mathrm{mRNA}$ and protein expression relative to patient smokers. Patient nonsmokers also had lower expression compared to control nonsmokers, but this difference was statistically significant only at the mRNA level. Representative protein bands from western blots, below the graph, show the quantified protein amounts. QRT-PCR and western blot assays overlapped by 14 subjects (three control nonsmokers, three control smokers, four schizophrenic non- 
smokers, and four schizophrenic smokers). Mean relative mRNA amounts $( \pm$ SEM) for each subject group are shown. $* p<0.05, * * p<0.01$ 
Table 2

Sequence for primers utilized in SYBR green QRT-PCR and sequencing

\begin{tabular}{llll}
\hline Gene & Forward primer & Reverse primer & Product Size (bp) \\
\hline QRT-PCR Primers & & & \\
CHRNA7 & TTTACAGTGGAATGTGTCAGAATATCC & TGTGGAATGTGGCGTCAAG & 125 \\
CHRFAM7A & GGAATCCCAGATGAGAGAGCTTATC & TGTGGAATGTGGCGTCAAAG & 236 \\
GAPDH & GGTATCGGAAGGACTC & GGATGATGTTCTGGAGAGC & 117 \\
CHRNA7 proximal promoter & AGTACCTCCCGCTCACACCTCG & ATGTTGAGTCCCGGAGCTGCAG & 271 \\
\hline
\end{tabular}


Table 3

CHRNA7 proximal promoter genotypes across diagnostic and smoking groups

\begin{tabular}{|c|c|c|c|}
\hline \multirow{2}{*}{ Diagnosis and smoking status } & \multicolumn{3}{|l|}{ Genotype } \\
\hline & $N / N(\%)$ & $\operatorname{SNP}(\%)$ & Total \\
\hline \multicolumn{4}{|c|}{ Postmortem brains evaluated by QRT-PCR } \\
\hline Control nonsmokers & $7(77.8)$ & $2(22.2)$ & 9 \\
\hline Control smokers & $6(75.0)$ & $2(25.0)$ & 8 \\
\hline Schizophrenic nonsmokers & $4(57.1)$ & $3(42.9)$ & 7 \\
\hline Schizophrenic smokers & $7(63.6)$ & $4(36.4)$ & 11 \\
\hline Total & 24 & 11 & 35 \\
\hline \multicolumn{4}{|l|}{ Expanded dataset } \\
\hline Control nonsmokers ${ }^{a}$ & $40(83.3)^{a}$ & $8(16.7)$ & 48 \\
\hline Control smokers & $14(77.8)$ & $4(22.2)$ & 18 \\
\hline Schizophrenic nonsmokers ${ }^{a, b}$ & $28(63.6)^{a, b}$ & $16(36.4)$ & 44 \\
\hline Schizophrenic smokers $b$ & $118(80.8)^{b}$ & $28(19.2)$ & 146 \\
\hline Total & 200 & 56 & 256 \\
\hline
\end{tabular}

SNP single nucleotide polymorphism

${ }^{a}$ Schizophrenic nonsmokers versus control nonsmokers ( $p=0.0276$, Fisher's exact test, one-tailed)

${ }^{b}$ Schizophrenic nonsmokers versus schizophrenic smokers ( $p=0.0174$, Fisher's exact test, one-tailed) 